\title{
A 70-Year History of Arborescent Vegetation of Inwood Park, Manhattan, New York, U.S.
}

\author{
Richard Stalter and Dwight Kincaid
}

\begin{abstract}
The arborescent vegetation located at three sites within Inwood Park, Manhattan, New York, U.S. was sampled by the quadrat method in October 2004 and May 2005 and compared with the trees present in the same quadrats on a map of trees at Inwood Park prepared by the federal Works Program Administration in 1935. Tulip poplar (Liriodendron tulipifera) was the dominant tree at the Moist Valley and South Slope sites in 1935 and 2005, whereas oak (Quercus) was the dominant genus at Dry Ridge in 1935 and 2005. Dogwood (Cornus florida) was the dominant subcanopy tree in 1935; it was unimportant in 2005, a victim of dogwood anthracnose. In terms of ecologic dominance, there has been no change in the first ranked genera at these sites in the past 70 years. Mean tree diameter (diameter at breast height) has increased from $32.3 \mathrm{~cm}$ (12.9 in) to $41.8 \mathrm{~cm}$ (16.7 in). The three sites have experienced a parallel pattern of increase in tree size from 1935 to 2005 . Nonnative trees were not important in Inwood Park in 2005.
\end{abstract}

Key Words. Inwood Park; Manhattan; New York City; urban forests.

Within the confines of New York City, U.S. there exists natural, woody vegetation that is probably similar to the vegetation observed by 17 th century Dutch settlers (Greller 1972). Today, most of this natural vegetation persists in municipal parks administered by the New York City Department of Parks and Recreation (Greller 1975; Stalter 1981).

During the 1930s, federal money was supplied through the Works Program Administration (WPA) to map, identify, and record the diameter at breast height (dbh at $1.37 \mathrm{~m}$ [4.5 ft]) of all trees in Inwood Park. After the completion of the WPA project in 1935, a map with tree identification, location, and dbh data was filed away and forgotten for nearly 40 years (Stalter 1981). The objective of this study was to compare community structure of the trees of Inwood Park as mapped in 1935 with that present in October 2004 through May 2005.

\section{METHODS}

The current study was conducted in Inwood Park (81 ha [200 ac]), located in northwest Manhattan (Figure 1). The quadrat method was used to sample trees presently growing in the park. Only trees with a dbh greater than $7.6 \mathrm{~cm}$ (3 in) were selected and measured in this study. Twenty-five $10 \mathrm{~m} \times 10 \mathrm{~m}(33 \mathrm{ft} \times 33$ $\mathrm{ft}$ ) quadrants were established at each of the three sites at Inwood Park: 1) Moist Valley, a forest dominated by Liriodendron tulipifera, $40^{\circ} 52^{\prime} 25^{\prime \prime} \mathrm{N}, 73^{\circ} 55^{\prime} 26^{\prime \prime} \mathrm{W}$; 2) South Slope, a southfacing moist forest dominated by Liriodendron tulipifera, $40^{\circ} 52^{\prime} 21^{\prime \prime} \mathrm{N}, 73^{\circ} 55^{\prime} 26^{\prime \prime} \mathrm{W}$; and 3) Dry Ridge, a ridge-top dominated by oak species, $40^{\circ} 52^{\prime} 15^{\prime \prime} \mathrm{N}, 73^{\circ} 55^{\prime} 22^{\prime \prime} \mathrm{W}$. The trees present in the 25 quadrats at each site in October 2004 through May 2005 were mapped on the original 1935 tree map of Inwood Park prepared by the WPA workers during the Great Depression in the United States. Although the purpose of the WPA was to put people to work rather than to pursue forestry, nevertheless, these tree data have historical value for understanding forest change in New York City.

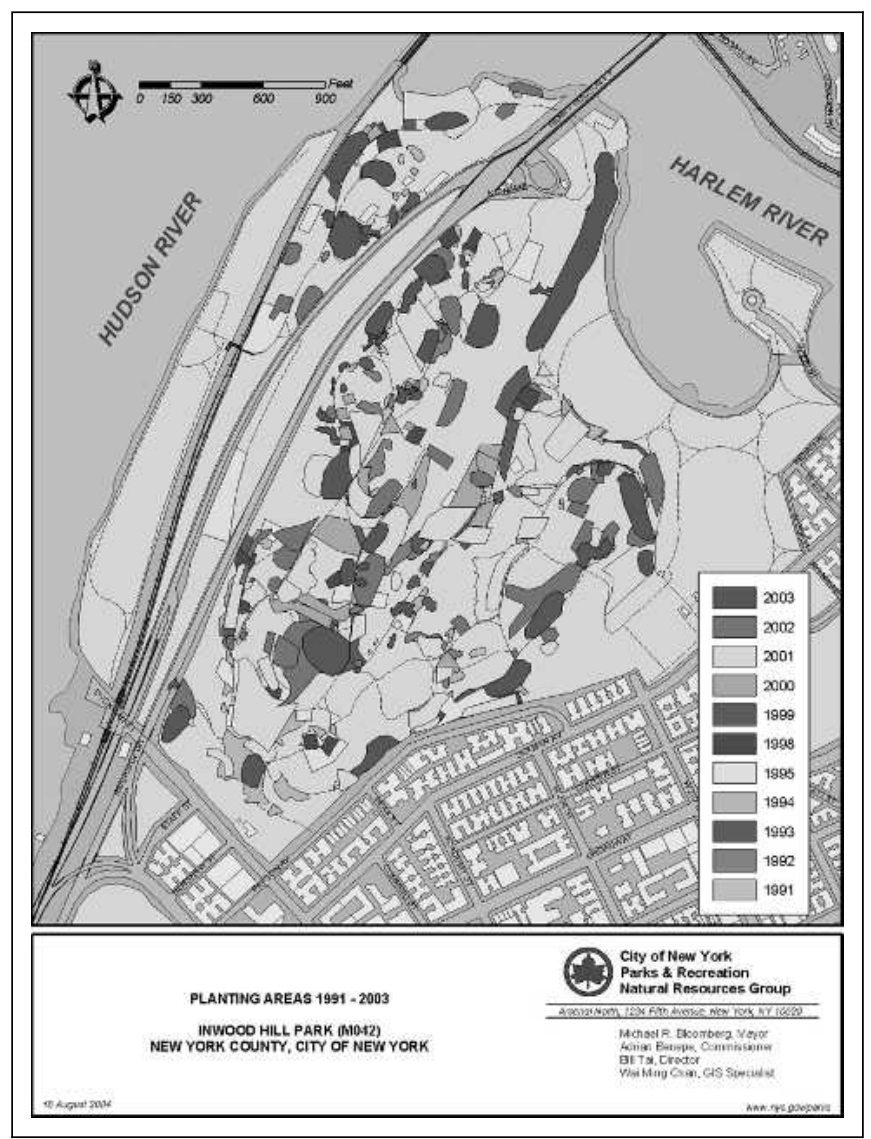

Figure 1. Inwood Park, in the northern tip of Manhattan, New York. Color-coded tree planting sites 1991 to 2003 by New York City Parks and Recreation. The geographic distribution of these plantings exceeded the range of our three study sites whose GPS coordinates are given in "Methods." 
Table 1. Species importance values (IV) in percentages for the 1935 and the 2005 census. $^{2}$

\begin{tabular}{|c|c|c|c|c|c|}
\hline Dominance rank & $\mathrm{N}$ & Relative density & Relative frequency & Relative dominance & Importance value \\
\hline \multicolumn{6}{|l|}{ Moist Valley, 1935} \\
\hline 1. Liriodendron tulipifera & 9 & $26.5(26.5)$ & $26.7(26.7)$ & $57.1(57.1)$ & $110.2(110.22)$ \\
\hline 2. Quercus spp. & 6 & $17.7(44.1)$ & $16.7(43.3)$ & $25.0(82.1)$ & $59.4(169.57)$ \\
\hline 3. Acer spp. & 8 & $23.5(67.6)$ & $20.0(63.3)$ & $5.6(87.7)$ & $49.1(218.69)$ \\
\hline 4. Fraxinus americana & 2 & $5.9(73.5)$ & $6.7(70.0)$ & $3.5(91.2)$ & $16.0(234.70)$ \\
\hline 5. Ulmus americana & 2 & $5.9(79.4)$ & 6.7 (76.7) & $2.1(93.3)$ & $14.7(249.36)$ \\
\hline 6. Carpinus caroliniana & 2 & $5.9(85.3)$ & $6.7(83.3)$ & $1.3(94.6)$ & $13.9(263.21)$ \\
\hline 7. Cornus florida & 2 & $5.9(91.2)$ & $6.7(90.0)$ & $1.0(95.6)$ & $13.6(276.78)$ \\
\hline 8. Betula lenta & 1 & $2.9(94.1)$ & $3.3(93.3)$ & $1.5(97.1)$ & $7.7(284.52)$ \\
\hline 9. Catalpa spp. & 1 & $2.9(97.1)$ & $3.3(96.7)$ & $1.5(98.5)$ & $7.7(292.26)$ \\
\hline 10. Juglans cinera & 1 & $2.9(100)$ & $3.3(100)$ & $1.5(100)$ & $7.7(300.00)$ \\
\hline \multicolumn{6}{|l|}{ Moist Valley, 2005} \\
\hline 1. Liriodendron tulipifera & 10 & $22.7(22.7)$ & $25.7(0.257)$ & $46.1(46.1)$ & $94.6(94.55)$ \\
\hline 2. Acer saccharum & 10 & $22.7(45.5)$ & $20.0(0.457)$ & $15.2(61.3)$ & $58.0(152.49)$ \\
\hline 3. Quercus rubra & 4 & $9.1(54.5)$ & $8.6(0.543)$ & $20.4(81.8)$ & $38.1(190.60)$ \\
\hline 4. Fraxinus americana & 4 & $9.1(63.6)$ & $11.4(0.657)$ & $0.9(82.6)$ & $21.4(212.00)$ \\
\hline 5. Quercus alba & 2 & $4.6(68.2)$ & $2.9(0.686)$ & $6.8(89.4)$ & $14.2(226.18)$ \\
\hline 6. Carya cordiformis & 2 & $4.6(72.7)$ & $5.7(0.743)$ & $3.0(92.5)$ & $13.3(239.48)$ \\
\hline 7. Ulmus americana & 2 & $4.6(77.3)$ & $5.7(0.800)$ & $2.9(95.3)$ & $13.1(252.59)$ \\
\hline 8. Betula lenta & 2 & $4.6(81.8)$ & $5.7(0.857)$ & $1.6(97.0)$ & $11.9(264.50)$ \\
\hline 9. Celtis occidentalis & 3 & $6.8(88.6)$ & $2.9(0.886)$ & $0.2(97.2)$ & $9.9(274.40)$ \\
\hline 10. Aralia spinosa & 2 & $4.6(93.2)$ & $2.9(0.914)$ & $0.3(97.5)$ & 7.7 (282.08) \\
\hline 11. Quercus velutina & 1 & $2.3(95.5)$ & $2.9(0.943)$ & $2.4(99.9)$ & $7.6(289.66)$ \\
\hline 12. Prunus serotina & 1 & $2.3(97.7)$ & $2.9(0.971)$ & $0.04(100)$ & $5.2(294.83)$ \\
\hline 13. Tsuga canadensis & 1 & $2.3(100)$ & $2.9(1.000)$ & $0.04(100)$ & $5.2(300.00)$ \\
\hline \multicolumn{6}{|l|}{ South Slope, 1935} \\
\hline 1. Liriodendron tulipifera & 25 & $31.3(31.3)$ & $31.5(31.5)$ & $68.0(68.0)$ & $130.7(130.68)$ \\
\hline 2. Quercus spp. & 14 & $17.5(48.8)$ & $20.4(51.9)$ & $12.1(80.1)$ & $50.0(180.68)$ \\
\hline 3. Acer spp. & 12 & $15.0(63.8)$ & $11.1(63.0)$ & $6.7(86.7)$ & $32.8(213.44)$ \\
\hline 4. Cornus florida & 11 & $13.8(77.5)$ & $13.0(75.9)$ & $2.1(88.8)$ & $28.8(242.23)$ \\
\hline 5. Betula lenta & 5 & $6.3(83.8)$ & $5.6(81.5)$ & $3.2(92.0)$ & $15.0(257.26)$ \\
\hline 6. Carya spp. & 5 & $6.3(90.0)$ & $5.6(87.0)$ & $2.9(95.0)$ & 14.7 (271.99) \\
\hline 7. Juglans cinera & 2 & $2.5(92.5)$ & $3.7(90.7)$ & $2.9(97.9)$ & $9.1(281.12)$ \\
\hline 8. Fraxinus americana & 2 & $2.5(95.0)$ & $1.9(92.6)$ & $0.5(98.4)$ & $4.9(285.97)$ \\
\hline 9. Nyssa sylvatica & 1 & $1.3(96.3)$ & $1.9(94.4)$ & $0.7(99.1)$ & $3.9(289.76)$ \\
\hline 10. Prunus spp. & 1 & $1.3(97.5)$ & $1.9(96.3)$ & $0.4(99.5)$ & $3.5(293.30)$ \\
\hline 11. Celtis occidentalis & 1 & $1.3(98.7)$ & $1.9(98.1)$ & $0.2(99.8)$ & $3.4(296.65)$ \\
\hline 12. Sassafras albidum & 1 & $1.3(100)$ & $1.9(100)$ & $0.2(100)$ & $3.4(300.00)$ \\
\hline \multicolumn{6}{|l|}{ South Slope, 2005} \\
\hline 1. Liriodendron tulipifera & 12 & $20.0(20.0)$ & $17.3(17.3)$ & $45.5(0.455)$ & $82.8(82.80)$ \\
\hline 2. Quercus rubra & 7 & $11.7(31.7)$ & $11.5(28.8)$ & $28.0(0.735)$ & $51.3(134.04)$ \\
\hline 3. Prunus serotina & 9 & $15.0(46.7)$ & $15.4(44.2)$ & $0.9(0.744)$ & $31.2(165.28)$ \\
\hline 4. Carya cordiformis & 6 & $10.0(56.7)$ & $11.5(55.8)$ & $7.3(0.817)$ & $28.9(194.15)$ \\
\hline 5. Sassafras albidum & 8 & $13.3(70.0)$ & $13.5(69.2)$ & $1.2(0.829)$ & $28.0(222.16)$ \\
\hline 6. Quercus alba & 3 & $5.0(75.0)$ & $5.8(75.0)$ & $7.0(0.899)$ & $17.8(239.94)$ \\
\hline 7. Cornus florida & 5 & $8.3(83.3)$ & $7.7(82.7)$ & $0.8(0.908)$ & $16.9(256.80)$ \\
\hline 8. Ulmus americana & 3 & $5.0(88.3)$ & $3.9(86.5)$ & $3.6(0.944)$ & $12.5(269.29)$ \\
\hline 9. Quercus prinus & 2 & $3.3(91.7)$ & $3.9(90.4)$ & $4.7(0.991)$ & $11.9(281.18)$ \\
\hline 10. Betula lenta & 1 & $1.7(93.3)$ & $1.9(92.3)$ & $0.6(0.997)$ & $4.2(285.34)$ \\
\hline 11. Acer saccharum & 1 & $1.7(95.0)$ & $1.9(94.2)$ & $0.12(0.998)$ & 3.7 (289.04) \\
\hline 12. Acer rubrum & 1 & $1.7(96.7)$ & $1.9(96.2)$ & $0.07(0.999)$ & $3.7(292.70)$ \\
\hline 13. Hamamelis virginiana & 1 & $1.7(98.3)$ & $1.9(98.1)$ & $0.07(1.000)$ & $3.7(296.37)$ \\
\hline 14. Fraxinus americana & 1 & $1.7(100)$ & $1.9(100)$ & $0.04(1.000)$ & $3.6(300.00)$ \\
\hline \multicolumn{6}{|l|}{ Dry Ridge, 1935} \\
\hline 1. Quercus spp. & 31 & 77.5 (77.5) & $69.2(69.2)$ & $95.0(95.0)$ & $241.7(241.69)$ \\
\hline 2. Betula lenta & 4 & $10.0(87.5)$ & $11.5(80.8)$ & $1.8(96.7)$ & $23.3(265.00)$ \\
\hline
\end{tabular}


Table 1. Species importance values (IV) in percentages for the 1935 and the 2005 census. $^{2}$ (continued)

\begin{tabular}{|c|c|c|c|c|c|}
\hline Dominance rank & $\mathrm{N}$ & Relative density & Relative frequency & Relative dominance & Importance value \\
\hline 3. Prunus spp. & 3 & $7.5(95.0)$ & $11.5(92.3)$ & $1.5(98.2)$ & $20.5(285.54)$ \\
\hline 4. Acer spp. & 1 & $2.5(97.5)$ & $3.9(96.2)$ & $1.2(99.5)$ & $7.6(293.11)$ \\
\hline 5. Robinia pseudoacacia & 1 & $2.5(100)$ & $3.9(100)$ & $0.5(100)$ & $6.9(300.00)$ \\
\hline \multicolumn{6}{|l|}{ Dry Ridge, 2005} \\
\hline 1. Quercus rubra & 43 & $43.0(43.0)$ & $28.4(28.4)$ & $47.0(47.0)$ & $118.4(118.37)$ \\
\hline 2. Quercus velutina & 7 & $7.0(50.0)$ & $9.0(37.3)$ & $13.2(60.2)$ & $29.2(147.52)$ \\
\hline 3. Quercus alba & 7 & $7.0(57.0)$ & $9.0(46.3)$ & $11.8(72.0)$ & $27.8(175.30)$ \\
\hline 4. Prunus serotina & 11 & $11.0(68.0)$ & $14.9(61.2)$ & $1.4(73.4)$ & $27.3(202.58)$ \\
\hline 5. Quercus prinus & 8 & $8.0(76.0)$ & $10.5(71.6)$ & $4.9(78.2)$ & $23.3(225.88)$ \\
\hline 6. Liriodendron tulipifera & 7 & $7.0(83.0)$ & $4.5(76.1)$ & $11.1(89.4)$ & $22.6(248.48)$ \\
\hline 7. Quercus coccinea & 3 & $3.0(86.0)$ & $4.5(80.6)$ & $3.6(92.9)$ & $11.1(259.53)$ \\
\hline 8. Betula lenta & 3 & $3.0(89.0)$ & $4.5(85.1)$ & $2.5(95.5)$ & $10.0(269.53)$ \\
\hline 9. Morus alba & 3 & $3.0(92.0)$ & $4.5(89.6)$ & $0.5(95.9)$ & $7.9(277.47)$ \\
\hline 10. Tilia cordata & 2 & $2.0(94.0)$ & $1.5(91.0)$ & $1.0(96.9)$ & $4.5(281.93)$ \\
\hline 11. Aesculus hippocastanum & 1 & $1.0(95.0)$ & $1.5(92.5)$ & $1.3(98.2)$ & $3.8(285.71)$ \\
\hline 12. Robinia pseudoacacia & 1 & $1.0(96.0)$ & $1.5(94.0)$ & $0.8(98.9)$ & $3.3(288.98)$ \\
\hline 13. Fraxinus americana & 1 & $1.0(97.0)$ & $1.5(95.5)$ & 0.7 (99.6) & $3.2(292.16)$ \\
\hline 14. Carya cordiformis & 1 & $1.0(98.0)$ & $1.5(97.0)$ & $0.2(99.8)$ & $2.7(294.82)$ \\
\hline 15. Populus deltoides & 1 & $1.0(99.0)$ & $1.5(98.5)$ & $0.2(100)$ & $2.7(297.48)$ \\
\hline 16. Prunus avium & 1 & $1.0(10.0)$ & $1.5(100)$ & $0.02(100)$ & $2.5(300.00)$ \\
\hline
\end{tabular}

${ }^{\mathrm{z}} \mathrm{IV}$ is the sum of relative density, relative frequency, and relative dominance. In the 1935 census, some taxa were identified only to genus. Integers denote the ecologic dominance rank of each species as measured by the IV method.

Loeb (1982) questioned the reliability of the New York City Department of Parks and Recreation's (NYCDPR) forest records. Loeb (1982) compared three tree map studies: the NYCDPR's topographic map series at Seton Falls Park in northern Bronx using forest records prepared in 1936 by the NYCDPR, his personal research in 1979, and a tree map prepared by Quinn Associates, Philadelphia, Pennsylvania, in 1981. Loeb surveyed a 5 ha (12.5 ac) portion of Seton Falls Park Forest and concluded that there were errors in identifications, tree diameter measurements, and "oversights in recording of species on the maps of the park." Loeb (1982) concluded, "Totally accurate arboreal spe-

Table 2. Density per ha of saplings (trees of diameter at breast height less than $7.6 \mathrm{~cm}(3 \mathrm{in})$ ) at three sites in 2005, Inwood Park, New York.

\begin{tabular}{lccc}
\hline Species & Moist Valley & South Slope & Dry Ridge \\
\hline Morus alba & 350 & & 250 \\
Acer platanoides & 200 & 50 & 50 \\
Fraxinus spp. & 250 & 700 & 350 \\
Acer saccharum & 400 & 100 & \\
Carya cordiformis & 100 & 350 & 100 \\
Liriodendron tulipifera & 150 & 150 & \\
Quercus alba & 150 & & 350 \\
Celtis occidentalis & 50 & 50 & 250 \\
Quercus prinus & 100 & & \\
Tilia cordata & & 50 & \\
Prunus serotina & & 150 & 3500 \\
Quercus rubra & & 50 & 450 \\
Sassafras albidum & & 100 & 450 \\
Prunus avium & 100 & 250 \\
Betula lenta & 50 & \\
Acer rubrum & & & 850 \\
Crataegus spp. & & & 50 \\
Pyrus calleryana & & & 400 \\
Pyrus malus & &
\end{tabular}

cies lists cannot be made from these records because some minor groups of species may not be included and misidentifications can cause the inclusion of species that were not present. Reliable statements of population density and dominance changes can only be made for dominant taxa." To address Loeb's concerns in this study, all species of oaks (Quercus) and all species of maples (Acer) were lumped as genera when comparing across years, so that past species misidentifications would not be an issue.

The trees identified within each quadrat in 2005 in the three sites mentioned were compared with trees identified within the same quadrats at the same sites located on the WPA map (City of New York, Department of Parks, Topographical Division 1935). Density (percent of total trees), frequency (percent of all points of occurrence across quadrats), relative dominance (percent total basal area), and importance value (IV, sum of relative density, relative frequency, and relative dominance) were calculated for all arborescent species in 1935 and 2005. Tree species were listed in decreasing order of IV (Kent and Coker 1992). Change in tree size (dbh) was subjected to two-way analysis of variance with date $(1935,2005)$, the three study sites, and the interaction term as effects (Sokal and Rohlf 1995). Shannon diversity (Pielou 1975) was calculated for the arborescent taxa in each study site for 1935 and 2005. Data were merged from the 1935 and 2005 census and correspondence analysis (Manly 2006) was used to ordinate the three study sites and the nine most dominant genera of trees.

Saplings (dbh less than $7.6 \mathrm{~cm}$ [ $3 \mathrm{in}]$ ) were sampled in $252 \mathrm{~m}$ $\times 4 \mathrm{~m}(6.6 \mathrm{ft} \times 13.2 \mathrm{ft})$ quadrants placed in the lower right corner of each $10 \mathrm{~m} \times 10 \mathrm{~m}(33 \mathrm{ft} \times 33 \mathrm{ft})$ quadrant in 2005 . No sapling data are available for 1935. Nomenclature follows Gleason and Cronquist (1991).

\section{RESULTS AND DISCUSSION}

At the Moist Valley in 1935 and in 2005, tulip poplar (Liriodendron tulipifera), red oak (Quercus rubra), and sugar maple (Acer 
saccharum) ranked one through three in relative density, relative dominance, and IV (Table 1). Together, they composed approximately $88 \%$ of the relative dominance (total basal area) of all tree species at this site. At Moist Valley, Liriodendron and Acer saccharum ranked first and second, respectively, in relative frequency, whereas oaks ranked third.

At the moist, south-facing South Slope, Liriodendron and species of oaks ranked first and second in relative density and relative dominance in 1935 and 2005. Together these species composed approximately $80 \%$ of the total basal area at this site. Frequency values for all tree species were low at the South Slope; Liriodendron ranked first in relative frequency followed by the oaks.

At Dry Ridge, oak dominated. Five oak species, red oak (Quercus rubra), black oak (Q. velutina), chestnut oak (Q. pri$n u s)$, white oak $(Q$. alba), and scarlet oak $(Q$. coccinea), composed $95 \%$ of the relative dominance at Dry Ridge in 1935 and $80.4 \%$ of the relative dominance in 2005 . Oak species together composed $78 \%$ of the relative density, $69 \%$ of the relative frequency, and a summed IV of 242 out of a possible 300 in 1935.

Density values (number per ha) for saplings, trees with dbh less than $7.6 \mathrm{~cm}$ (3 in), are presented in Table 2. Dry Ridge has the greatest number of saplings per hectare $(7,350)$. Black cherry (Prunus serotina), an edge and/or successional species, was most abundant (3,500 per ha). Few $P$. serotina with a dbh greater than $7.6 \mathrm{~cm}$ ( 3 in) were observed at Dry Ridge; most occurred at the sunlit edge of the forest.

The South Slope and Moist Valley sites had fewer saplings than Dry Ridge. White ash (Fraxinus) was most abundant at the South Slope (700 per ha) followed by hickory (Carya) (350 ha). Liriodendron, the dominant canopy species at South Slope had 150 per ha as did P. serotina.

At Moist Valley, Acer saccharum ranked first in number of saplings (400 ha). Acer saccharum was the second most abundant large tree followed by Liriodendron. The sapling number for Liriodendron was 150 per ha. The alien white mulberry (Morus alba), Fraxinus spp., and the alien Norway maple (Acer platanoides) were represented by 350, 250, and 200 saplings, respectively.

At South Slope, density and frequency data for saplings trees with a dbh less than $7.6 \mathrm{~cm}$ are presented in Table 2. Bitternut (Carya cordiformis) saplings were more abundant than Quercus and Liriodendron. At Dry Ridge, Prunus serotina was the most abundant sapling outnumbering Quercus rubra, the second ranked sapling, by fourfold. Dry Ridge had the greatest number of saplings/ha and the greatest diversity of tree sapling species. Quercus rubra, the dominant tree at Dry Ridge, ranked third in number of saplings per hectare, 450, as did sassafras (Sassafras albidum) (Table 2).

There has been no change in the first ranked taxon at each of the three study sites over 70 years from 1935 and 2005 (Table 1). At the Moist Valley and South Slope sites, Liriodendron tulipifera was the dominant tree, whereas Quercus was the dominant genus at Dry Ridge. Tree of heaven (Alianthus altissima) and ginkgo (Ginkgo biloba), both nonnative species, were no longer found at Moist Valley. The ginkgo was obviously planted in the last century or earlier and probably was outshaded as the forest matured. Alianthus altissima is not shade-adapted and probably succumbed in the competition for light, although this species may have potential to invade gaps in the forest canopy (Knapp and Canham 2000). Canadian hemlock (Tsuga canadensis), identified at Moist Valley in 2005, was planted by the Parks Department.

At South Slope, oaks have increased in relative dominance, whereas maples (Acer spp.) and sweet birch (Betula lenta) have declined since 1935. Hickory (Carya) and American elm (Ulmus americana) have increased in relative dominance (Table 1). At Dry Ridge, oaks have dominated for the past 70 years. The relative dominance value for all oaks has decreased slightly from $95 \%$ to $80 \%$ (Table 1). At Dry Ridge, cherry (Prunus) has shown a slight decline in relative dominance but had the greatest number of individuals in the (less than $7.6 \mathrm{~cm}$ dbh) sapling class (Table 2). Prunus serotina, an earlier successional species, does not compete well with the more shade-tolerant oaks at Dry Ridge.

Early in the 20th century in northern Queens County, New York, Harper (1917) reported that $Q$. velutina, $Q$. alba, Carya spp., and American chestnut (Castanea dentata, dying) accounted for $41 \%$ of the trees. In Queens County, Greller (1972) identified 43 "witness trees" listed in deeds and surveyor records to delineate property lines from 1685 to 1764 . Among the witness trees listed were 14 black oak (33\%), seven walnuts, Carya spp. (16\%), six white oaks (14\%), five chestnuts (12\%), and 11 additional individual tree species. At Inwood Park, oaks comprise the majority of the individuals at Dry Ridge and are

Table 3. Comparison of relative density of trees in the forests of Inwood Park in the 1935 and 2005 study.

\begin{tabular}{|c|c|c|c|}
\hline Taxon & 1935 Census & & 2005 Census \\
\hline \multirow[t]{6}{*}{ 1. Quercus } & 0.331 & Quercus & 0.427 \\
\hline & & Q. rubra & 0.265 \\
\hline & & Q. alba & 0.059 \\
\hline & & $Q$. prinus & 0.049 \\
\hline & & $Q$. velutina & 0.039 \\
\hline & & Q. coccinea & 0.015 \\
\hline 2. Liriodendron tulipifera & 0.214 & & 0.142 \\
\hline \multirow[t]{3}{*}{ 3. Acer } & 0.136 & Acer & 0.059 \\
\hline & & A. saccharum & 0.054 \\
\hline & & A. rubrum & 0.005 \\
\hline 4. Cornus florida & 0.084 & & 0.025 \\
\hline 5. Betula lenta & 0.065 & & 0.029 \\
\hline 6. Carya cordiformis & 0.032 & & 0.044 \\
\hline 7. Fraxinus americana & 0.026 & & 0.029 \\
\hline \multirow[t]{3}{*}{ 8. Prunus } & 0.026 & Prunus & 0.108 \\
\hline & & P. serotina & 0.103 \\
\hline & & P. avium & 0.005 \\
\hline 9. Juglans cinera & 0.019 & & - \\
\hline 10. Carpinus caroliniana & 0.013 & & - \\
\hline 11. Ulmus americana & 0.013 & & 0.025 \\
\hline 12. Catalpa spp. & 0.006 & & - \\
\hline 13. Celtis occidentalis & 0.006 & & 0.015 \\
\hline 14. Liquidambar styraciflua & 0.006 & & - \\
\hline 15. Nyssa sylvatica & 0.006 & & - \\
\hline 16. Robinia pseudoacacia & 0.006 & & 0.005 \\
\hline 17. Sassafras albidum & 0.006 & & 0.039 \\
\hline 18. Morus alba & - & & 0.015 \\
\hline 19. Tilia cordata & - & & 0.010 \\
\hline 20. Aralia spinosa & - & & 0.010 \\
\hline 21. Aesculus hippocastanum & - & & 0.005 \\
\hline 22. Hamamelis virginiana & - & & 0.005 \\
\hline 23. Populus deltoides & - & & 0.005 \\
\hline 24. Tsuga canadensis & - & & 0.005 \\
\hline
\end{tabular}


Table 4. Tree plantings at Inwood Park during Fall 2004 to Fall 2005. ${ }^{\mathrm{z}}$

\begin{tabular}{llll}
\hline & \multicolumn{3}{c}{ Number of trees } \\
\cline { 2 - 4 } \multicolumn{1}{c}{ Species } & Fall 2004 & Spring 2005 & Fall 2005 \\
\hline Quercus rubra & 173 & 122 & 195 \\
Liriodendron tulipifera & 120 & 105 & 109 \\
Celtis occidentalis & 100 & 70 & 16 \\
Acer rubrum & 96 & & 15 \\
Quercus alba & 52 & 36 & 12 \\
Pinus strobus & 37 & & 21 \\
Quercus prinus & 29 & 74 & 75 \\
Acer saccharum & 14 & & 95 \\
Quercus palustris & 12 & & 51 \\
Quercus velutina & 10 & 12 & \\
Carpinus caroliniana & 9 & 9 & \\
Ostrya virginiana & 7 & & \\
Amelanchier canadensis & 1 & & \\
Betula lenta & 1 & 74 & \\
Fraxinus americana & & 36 & 16 \\
Quercus $\times$ heterophylla & & 30 & \\
Carya cordiformis & & 19 & 12 \\
Liquidambar styraciflua & & 15 & \\
Betula nigra \\
Betula populifolia
\end{tabular}

${ }^{\mathrm{z}}$ Figure 1 maps the approximate location of tree plantings from 1991 to 2003.

common at South Slope. Acer, represented by $4.7 \%$ of witness trees, is represented by $45.5 \%$ and $3.4 \%$ of trees at Moist Valley and South Slope, respectively. Castanea dentata, represented by $11.6 \%$ of witness trees, has succumbed to chestnut blight in the early 20th century. No Liriodendron were included in witness tree data, yet it is the most important taxon at Moist Valley and South Slope. Liriodendron is an invader after disturbance (Pittillo 2007), which may account for its $23 \%$ and $20 \%$ abundance at Moist Valley and South Slope of Inwood Park, respectively (Table 1).

Quercus was the dominant tree genus in northern Queens County parks (Greller 1972, 1975). Quercus rubra was the dom- inant tree in the uplands of Cunningham Park, Queens County, New York (Lefkowitz and Greller 1973) and was the dominant tree at Dry Ridge at Inwood Park (Table 1). Lefkowitz and Greller (1973) reported that Liriodendron tulipifera, Cornus florida, Acer rubrum, Quercus velutina, and Liquidambar styraciflua were also common in northern Queens forests with importance values of $10 \%$ or higher in at least one of the five morainal areas sampled. Liriodendron also had the highest importance values at Moist Valley and South Slope at Inwood Park (Table 1).

Stalter (1981) studied the arborescent vegetation at Alley Park, New York, in 1975. The trees present at Alley Park in 1975 were compared with the tree species present at the same site on a map prepared by the WPA workers in 1936. Quercus rubra was ranked first in relative dominance in 1936 and 1975. Black oak, Quercus velutina, ranked second in relative dominance in 1936 and 1975. Black oak ranked fourth in IV in 1936 and second in 1975. Dogwood, Cornus florida, a subcanopy species, ranked second in IV in 1936 and third in 1975. The decline of dogwood in 1975 may have been the result of a crippling ice storm in December 1974 (Stalter 1981).

Stalter (1981) reported that Prunus serotina and Cornus florida had the greatest number of saplings in Alley Park, 417/ha and 333/ha, respectively, whereas $Q$. rubra (83/ha) and $Q$. alba (42/ha) were less abundant. Prunus serotina saplings were also the most abundant tree species present at Dry Ridge in the current study at Inwood Park (Table 2).

The data on tree species presented in Table 3 addressed Loeb's (1982) problem with tree species identification. Oaks and maples were lumped as genera. The two genera with the greatest percent basal area at Moist Valley and South Slope were Liriodendron and Quercus, whereas Quercus was dominant at Dry Ridge. These genera cannot be confused with other genera at Inwood Park. Tulip poplar, oaks, and maples composed over $80 \%$ of the relative dominance of all tree species at the three sites selected for study at Inwood Park (Table 1). The other tree species at Inwood Park were unimportant in 1935 and in 2005, no other tree species attained a percent basal area value greater than $7 \%$.

In 2005, nonnative saplings were unimportant at Inwood Park, with the exception of white mulberry and Norway maple at the

Table 5. Species diversity and tree size at three locations in the forests of Inwood Park censused in 1935 and 2005.

\begin{tabular}{|c|c|c|c|c|c|c|}
\hline & & 1935 Census & & & & 2005 Census \\
\hline & Species & dbh $(\mathrm{SD})$ maximum & & Species & & dbh $(\mathrm{SD})$ maximum \\
\hline Moist Valley & 10 & $36.01(24.19) 91.4 \mathrm{~cm}$ & & 13 & & $46.01(32.84) 139.7 \mathrm{~cm}$ \\
\hline South Slope & 13 & 28.51 (19.02) 121.9 & & 14 & & 38.00 (29.84) 99.0 \\
\hline Dry ridge & 5 & 36.70 (23.67) 101.6 & & 16 & & 42.25 (25.21) 125.7 \\
\hline Total & 17 & 32.29 (21.72) 121.9 & & 25 & & $41.81(28.38) 139.7$ \\
\hline \multicolumn{7}{|c|}{ Two-way ANOVA } \\
\hline Effect & df & SS & $\mathrm{F}$ & & $P$ & $R^{2}$ \\
\hline Date & 1 & 5,388 & 8.19 & & 0.0045 & 0.022 \\
\hline Site & 2 & 3,836 & 2.915 & & 0.0555 & 0.016 \\
\hline Date $\times$ site & 2 & 321 & 0.244 & & 0.78 & 0.001 \\
\hline Unexplained & 352 & 231,577 & & & & 0.951 \\
\hline Total & 357 & 243,577 & & & & \\
\hline
\end{tabular}

${ }^{\mathrm{z}}$ Results from $2510 \mathrm{~m} \times 10 \mathrm{~m}$ quadrats at each census. In the 1935 census, some taxa were identified only to genus (Table 1). Species number, mean dbh with SD, and maximum. The data are the upper table is analyzed by two-way ANOVA below.

$\mathrm{dbh}=$ diameter at breast height; $\mathrm{SD}=$ standard deviation; ANOVA $=$ analysis of variance; $\mathrm{SS}=$ sum of squares for $\mathrm{dbh}$. 


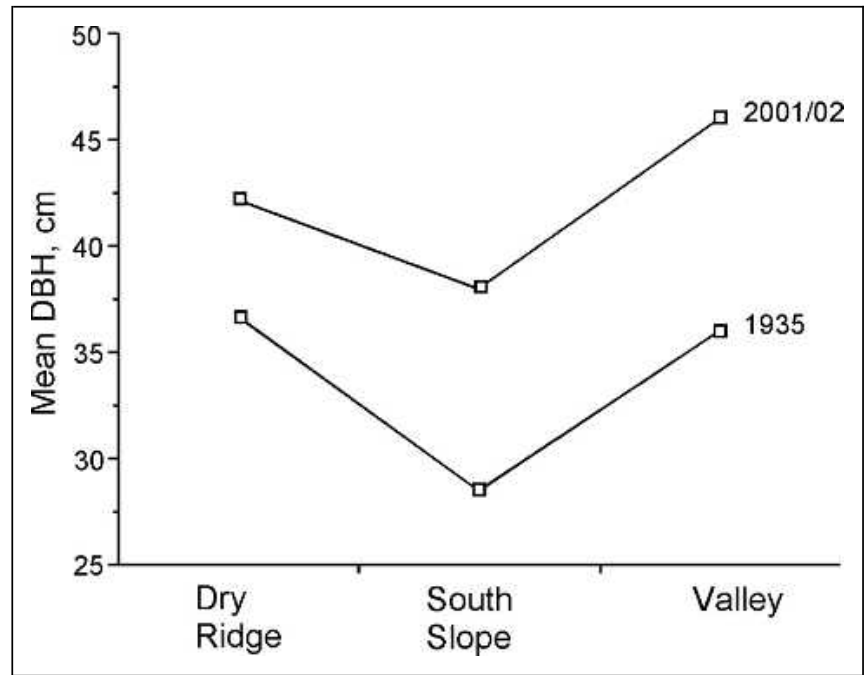

Figure 2. Interaction graph of mean diameter at breast height (dbh) for the three sites comparing the 1935 with the 2004 to 2005 census of Inwood Park, New York. In two-way analysis of variance, interaction $F_{2,353}=0.24, P=0.78$. Mean $\mathrm{dbh}$ has increased in parallel fashion at each site.

Moist Valley site. Neither of these two taxa were present at Moist Valley in 1935. Glaeser and Kincaid (2005) report a recent outbreak of a nonnative invasive tree, amur cork (Phellodendron amurense), in the forests of Queens County of New York City. This species ranked third in overall dominance and second in relative abundance in a 0.5 ha study plot in Forest Park, Queens (Glaeser and Kincaid 2005). The situation at Inwood Park bears monitoring because $P$. amurense, a hardy urban tree, has been planted throughout the five boroughs of New York City.

Park personnel planted trees in Inwood Park from 1991 to Fall 2005 (Table 4). Only the numbers from Fall 2004 to Fall 2005 are presented in Table 4. Over 18,000 trees of 20 species were planted across approximately $33 \%$ of the area of the park during this 14 year period. Over $90 \%$ of the plantings have survived (Richard Love, pers. comm.).

In two-way analysis of variance (ANOVA) (Table 5), mean dbh was significantly different between the 1935 and the 2005 census (32.3 cm [12.9 in] versus $41.8 \mathrm{~cm}$ [16.7 in], respectively; $\left.\mathrm{F}_{1,352}=8.19, P=0.0045\right)$, although census date explained only $2.2 \%$ of the variation in dbh $\left(R^{2}\right)$. Among the three study sites,

Table 6. Shannon diversity and simple species diversity for trees at Inwood Park, New York, in 1935 and in 2005.

\begin{tabular}{llll}
\hline Year & Moist Valley & South Slope & Dry Ridge \\
\hline 1935 & & & \\
$\quad$ Simple diversity & 10 & 12 & 5 \\
$\quad$ Shannon diversity & 1.976 & 1.976 & 0.807 \\
$2005^{z}$ & & & \\
$\quad$ Simple diversity & 11 & 11 & 11 \\
$\quad$ Shannon diversity & 2.101 & 2.102 & 1.222 \\
2005 & & & \\
Simple diversity & 13 & 14 & 16 \\
$\quad$ Shannon diversity & 2.253 & 2.317 & 2.036 \\
\hline
\end{tabular}

${ }^{\text {zThe }} 2005$ site reflects species merged into genera (i.e., Acer, Quercus, Prunus) corresponding to the 1935 census.

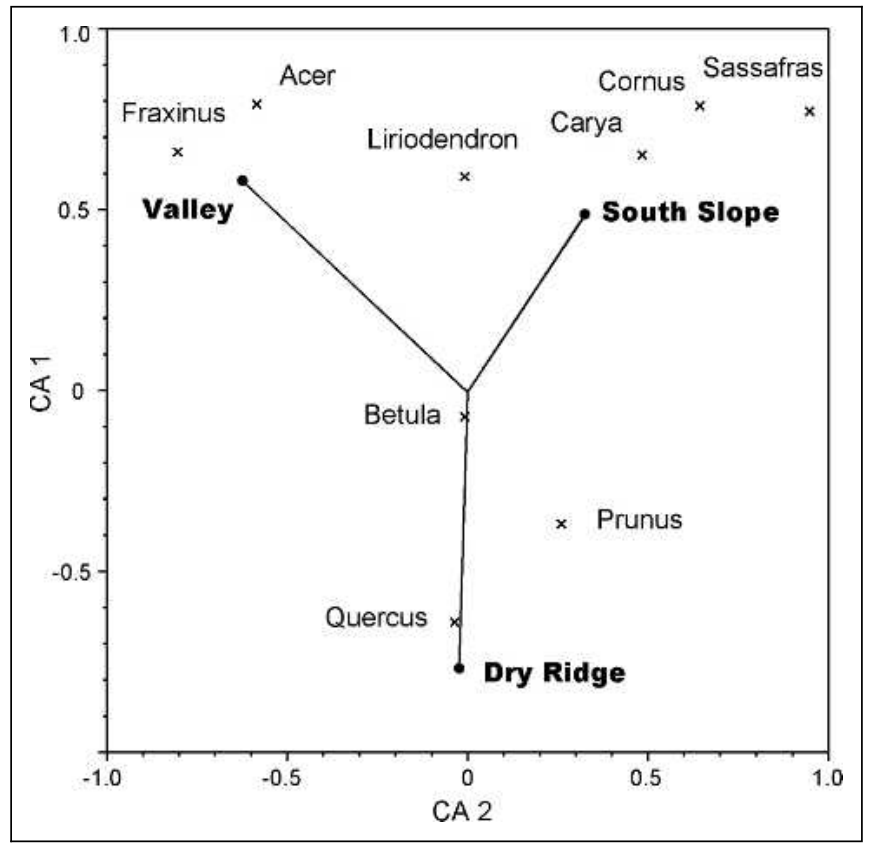

Figure 3. Correspondence analysis ordinating the three sites and the nine most dominant genera of trees. Data merged from the 1935 and 2004 to 2005 census. The rays indicate the direction and distance from the origin of the three sites as ordinated by generic composition (Anonymous 2007).

mean dbh was not significantly different $\left(\mathrm{F}_{2,352}=2.92, P=\right.$ 0.056). The census date $\times$ study site interaction in ANOVA was not significant $\left(\mathrm{F}_{2,352}=0.24, P=0.8\right)$, which supports the visualization in Figure 2 that the three sites experienced a parallel pattern of increase in tree size from the 1935 to the 2005 census.

The correspondence analysis (CA) of Figure 3 displays the significant separation $(P<0.0001)$ of Dry Ridge, South Slope, and Moist Valley on the basis of the presence and abundance of the nine most dominant tree genera for the merged 1935 and 2005 census. The community data from 1935 and 2005 were merged because of their similarity. CA graphs generated for the 1935 data and independently for 2005 were nearly indistinguishable.

In the CA ordination of genera, Quercus was the most common of the nine genera of trees at Dry Ridge. Prunus, a successional species, is more common at Dry Ridge than at the other sites. Betula was the most evenly distributed taxon across the sites as seen by its location at the origin of the CA graph. Liriodendron was most common at South Slope and Moist Valley. The three genera clustered at South Slope were Carya, Cornus, and Sassafras. Sassafras was found only at South Slope. Cornus, a subcanopy species, favors South Slope, was present at Moist Valley, and absent at Dry Ridge. Carya, a climax species, occurred at all three sites, but was most common at South Slope. Acer was common at Moist Valley and South Slope but was represented by a single tree at Dry Ridge. Fraxinus was found at all three sites but was most common in Moist Valley. Shannon diversity and simple species diversity for trees has increased slightly since the 1935 census, although less so when the 2005 data are merged into genera to conform to the 1935 census (Table 6). 


\section{CONCLUSION}

There has been little change in the dominant taxa at Moist Valley, South Slope, and Dry Ridge at Inwoood Park from 1935 to 2005 (Table 1), although mean tree size (dbh) has increased (Figure 2). Tree size (dbh) was not significantly different among our three study sites. At Moist Valley and South Slope, Liriodendron tulipifera was dominant, whereas Quercus was dominant at Dry Ridge. These taxa were dominant at our sites at Inwood Park over the past 70 years. Barring major disturbances, they will continue to remain dominant in decades to come, because of their climax role in ecologic succession in our local forests of the temperate deciduous biome. Oaks have long been an important component of the forests in metropolitan New York (O'Gorman 1934; Greller 1972; Stalter 1981).

Acknowledgments. We greatly acknowledge the help of the following individuals who assisted in the research at Inwood Park: Cheryl Nenn who granted permission to conduct the study; Steve Rizick, who provided the WPA maps of Inwood Park; especially Chris Syrett, Tony Rho, Adam Maxwell, and Tim Wehslcus who provided valuable field assistance at Inwood Park; and Daniel Podd and Francis Lavi for their assistance in the preparation of this article.

\section{LITERATURE CITED}

Anonymous. 2007. JMP statistics and graphics guide, Release 7. SAS Institute Inc., Cary, NC.

City of New York, Department of Parks, Topographical Division. 1935. Topographical Map Portion of Inwood, Manhattan, New York.

Glaeser, C.W., and D. Kincaid. 2005. The non-native invasive Phellodendron amurense Rupr. in a New York City Woodland. Arboricultural Journal 28:151-164.

Gleason, H.A., and A. Cronquist. 1991. Manual of Vascular Plants of Northeastern United States and Adjacent Canada. New York Botanical Gardens, Bronx, NY.

Greller, A.M. 1972. Observations on the forests of Northern Queens County, Long Island, from colonial times to the present. Bulletin of the Torrey Botanical Club 99:202-206.

. 1975. Persisting natural vegetation in Northern Queens County, New York. Environmental Conservation 2:61-69.

Harper, R.M. 1917. The native plant population of Northern Queens County, Long Island. Torreya 17:131-142.

Kent, M., and P. Coker. 1992. Vegetation Description and Analysis. A Practical Approach. CRC Press, London, UK.

Knapp, L.B., and C.D. Canham. 2000. Invasion of old growth forests in New York by Ailanthus altissima: Sapling growth and recruitment in canopy gaps. The Journal of the Torrey Botanical Society 127: 307-315.

Lefkowitz, A., and A. Greller. 1973. The distribution of tree species on the uplands of Cunningham Park, Queens County, New York. Bulletin of the Torrey Botanical Club 100:313-318.

Loeb, R.E. 1982. Seton Falls Park: A land use history. Bronx County Historical Society Journal 18:18-32.

Manly, B.F.J. 2006. Multivariate Statistical Methods: A Primer, 3rd ed. Chapman \& Hall, London, UK.

O'Gorman, W. ed. 1934. Newtown Records. The Queens Borough Public Library, Jamaica, NY.

Pielou, E.C. 1975. Ecological Diversity. John Wiley, New York, NY.

Pittillo, J.D. 2007. Will southern Appalachian forests be dominated by tulip trees in the future? Chinquapin 15:26.

Sokal, R.R., and F.J. Rohlf. 1995. Biometry, 3rd ed. W.H. Freeman, New York, NY.

Stalter, R. 1981. A thirty nine year history of arborescent vegetation of Alley Park, Queens County, New York. Bulletin of the Torrey Botanical Club 108:485-487.
Richard Stalter

Professor

St. John's University

Department of Biological Sciences

Jamaica, NY 11439, U.S.

stalterr@stjohns.edu

Dwight Kincaid (corresponding author)

Professor

Lehman College

City University of New York

Bronx, NY 10468, U.S.

dkincaid49@yahoo.com

Résumé. La végétation arborescente localisée au sein de trois sites du parc Inwood à Manhattan dans l'état de New York a été échantillonnée avec la méthode des quadrants en octobre 2004 et en mai 2005, puis comparée par la suite aux arbres présents dans les mêmes quadrants au moyen de cartes de végétation arborescente produites par l'Administration fédérale de gestion des travaux en 1935. Le tulipier (Liriodendron tulipifera) était l'arbre dominant dans les sites Moist Valley et South Slopes en 1935 et en 2005 tandis que le chêne (Quercus spp.) était le genre dominant dans le site Dry Ridge en 1935 et en 2005. Le cornouiller fleuri (Cornus florida) était l'arbre dominant du sousétage en 1935; il est aujourd'hui peu répandu en raison de l'anthracnose du cornouiller. En terme de dominance écologique, il n'y a pas eu de changement dans la génération dominante au cours des 70 dernières années au sein des trois sites étudiés. Le diamètre moyen des arbres au DHP s'est accrû de $32,2 \mathrm{~cm}$ à $41,8 \mathrm{~cm}$. Les trois sites ont connu un patron parallèle de croissance dans la dimension des arbres de 1935 à 2005. Les espèces non indigènes sont peu présentes au parc Inwood actuellement.

Zusammenfassung. Im Oktober 2004 und Mai 2005 wurde die Baumvegetation an drei Stellen im Inwood-Park, New York per Planquadrat-Methode aufgenommen und mit den im Jahr 1935 erfassten Bäumen des gleichen Planquadrats verglichen. 1935 und 2005 waren Tulpenbäume im Feuchten Tal und an den Südhängen die populärste Baumart, während Eichenarten im gleichen Zeitraum am Standort: Trockener Kamm dominierten. Hartriegel war 1935 die dominante Unterholzart, ist aber gegenwärtig unwichtig, ein Opfer der HartriegelAnthracnose. In Bezug auf ökologische Dominanz gab es in den letzten 70 Jahren keine Änderung bei den erstgenannten Arten auf den drei untersuchten Standorten. Der mittlere Baumdurchmesser stieg an von 32,2 auf 41,8 cm. Die drei Standorte erlebten von 1935 bis 2005 ähnliche Muster bei der Veränderung der Baumgröße. Die nicht-nativen Baumarten sind gegenwärtig in Inwood-Park nicht wichtig.

Resumen. La vegetación arborescente localizada en tres sitios de Inwood Park, Manhattan, New York fueron muestreadas por el método del cuadrante en Octubre de 2004 y Mayo de 2005, y fueron comparadas con los árboles presentes en los mismos cuadrantes en un mapa de vegetación arborescente en Inwood Park elaborado en 1935 por el Works Program Federal Administration. Liriodendron tulipifera fue el árbol dominante en los sitios Moist Valley y South Slope en 1935 y 2005, Quercus spp. fue el género dominante en el sitio Dry Ridge en 1935 y 2005. Cornus florida fue dominante en el estrato bajo en 1935; y también víctima de la antracnosis. En términos de dominancia ecológica no ha habido cambio en el primer género en estos tres sitios de estudio en los pasados 70 años. El diámetro medio normal (dbh) aumentó de $32.2 \mathrm{~cm}$ a $41.8 \mathrm{~cm}$. Los tres sitios han experimentado un patrón paralelo de incremento en tamaño de 1935 a 2005. Las especies maderables no nativas no son importantes en Inwood Park, en el momento actual. 